\title{
Life history of Lepidostoma hirtum in an Iberian stream and its role in organic matter processing
}

\author{
Azevedo-Pereira H.V.S. ${ }^{1}{ }^{*}$, Graça M.A.S. ${ }^{1}$ \& González J.M. ${ }^{2}$ \\ ${ }^{1}$ IMAR - Instituto do Mar - CIC, Departamento de Zoologia, Universidade de Coimbra, 3004-517 Coimbra, Portugal \\ ${ }^{2}$ Departamento Matemáticas y Física Aplicadas y Ciencias de la Naturaleza, Universidad Rey Juan Carlos, C/ Tulipán, \\ s/n, E 28933 Móstoles, Madrid, España \\ (*Author for correspondence: E-mail: rike@bio.ua.pt)
}

Received 13 March 2005; in revised form 12 August 2005; accepted 28 August 2005

Key words: detritus fragmentation, secondary production, shredder

\begin{abstract}
The goal of this research was to determine the role of Lepidostoma hirtum Fabricius 1775 in the fragmentation of allochtonous organic material, in a segment of a mountain river in central Portugal. For this purpose, we measured leaf fragmentation and growth rates at four temperatures $\left(9,12,15\right.$ and $\left.18{ }^{\circ} \mathrm{C}\right)$ and four leaf types (alder, Alnus glutinosa L.; oak, Quercus andegavensis Hy; poplar, Populus $\times$ canadensis Moench; and chestnut, Castanea sativa Mill.). Growth rates ranged from 0.012 to $0.049 \mathrm{mg}$ AFDW day ${ }^{-1}$ with no significant effect of temperature and leaf type. Fragmentation/consumption rates were significantly higher for alder $\left(1.62 \mathrm{mg}\right.$ animal $\left.{ }^{-1} \mathrm{day}^{-1}\right)$ than for other leaf types, and significantly lower at $9{ }^{\circ} \mathrm{C}$ $\left(0.70 \mathrm{mg}\right.$ animal $\left.{ }^{-1} \mathrm{day}^{-1}\right)$ than at any other temperature $\left(1.12 \mathrm{mg}\right.$ animal $\left.^{-1} \mathrm{day}^{-1}\right)$. In the studied stream, L. hirtum larvae had a univoltine life history, with an asynchronous development. Secondary production of L. hirtum ranged from $53.95 \mathrm{mg} \mathrm{m}^{-2}$ year $^{-1}$ (pools) to $63.12 \mathrm{mg} \mathrm{m}^{-2}$ year $^{-1}$ (riffles). Annual $\mathrm{P} / \mathrm{B}$ ratios differ between habitats: they were 4.01 year $^{-1}$ for pools and 4.49 year $^{-1}$ for riffles. Considering the average density of this species in the study river and their consumption rates, this species has the potential to fragment 8.6 times the mean annual standing stock of organic matter, in the study location.
\end{abstract}

\section{Introduction}

Allochtonous organic material has been referenced as the major energy source for small forest streams (e.g. Fisher \& Likens, 1973; Graça, 1993; Abelho, 2001). Riparian vegetation produces high quantities of detritus that enters in headwater streams and is used as an energy source by microorganisms and invertebrates (Abelho, 2000). The quantity and quality of leaf material entering streams depends on the type of riparian vegetation and the properties of the stream, such as its retention capabilities (Friberg \& Jacobsen, 1999) and water chemistry, particularly nutrients and hardness (Suberkropp \& Chauvet, 1995).
Leaves entering streams also differ in their physical and chemical properties. Those differences influence microbial decomposition (Canhoto \& Graça, 1996) and invertebrate feeding and growth (Canhoto \& Graça, 1996; Friberg \& Jacobsen, 1999; González \& Graça, 2003). Invertebrate feeding and growth are also affected by temperature, as it is an important determinant of metabolism (Sutcliffe et al., 1981; Nolen \& Pearson, 1993; González \& Graça, 2003).

Detritivores feeding on coarse particulate organic matter (i.e., shredders) may account up to $40 \%$ of the total invertebrates in low-order streams (Graça et al., 2001a) and they may be limited by food (Gee, 1988; Dobson \& Hildrew, 
1992). The ingestion rates of shredders are strongly affected by the physico-chemical quality of the leaves and by environmental temperatures (e.g. González \& Graça, 2003).

In a previous paper, González \& Graça (2003) estimated the amount of leaf litter ingested by the shredding caddis fly Sericostoma vittatum Rambur in a small stream in central Portugal. They found that S. vittatum had two overlapping cohorts, each needing about one year to develop. Secondary production was $0.44 \mathrm{~g} \mathrm{~m}^{-2}$ year $^{-1}$ and annual leaf litter consumption by this species was estimated as 14-22 $\mathrm{g} \mathrm{m}^{-2}$, depending on the diet.

The aim of this study was to determine, in a first stage, the temporal dynamics and to quantify the secondary production of a population of the shredder trichoptera Lepidostoma hirtum Fabricius that was sympatric with the $S$. vittatum population studied by González \& Graça (2003). In a second stage, we tested in the laboratory the null hypothesis that leaf fragmentation rates of L. hirtum, were independent of leaf type and temperature. Data on processing rates and densities allow us to determine the relative importance of this species in leaf litter processing in the studied segment of the headwater stream.

\section{Materials and methods}

\section{Population dynamics}

This research was carried out in the S. João stream, Lousã Mountains, central Portugal. The study site was located just upstream of the city of Lousã (5th order stream). In this location, the stream is bordered by diverse riparian trees, including chestnut (Castanea sativa Mill), pine (Pinus pinaster Aiton), eucalyptus (Eucalyptus globulus Labill), acacia (Acacia dealbata Link), poplar (Populus $\times$ canadensis Moench) and willow (Salix sp.). At the sampling site, riffles and run areas occupied approximately $76 \%$ of the stream, in which cobbles and pebbles constituted the substrate. Specimens of L. hirtum were collected monthly between November of 2000 and October of 2001. During that period, daily mean water temperatures ranged from 3.9 to $19.9{ }^{\circ} \mathrm{C}$ (González \& Graça, 2003).
Eleven random samples were taken on each sampling date: seven in riffles, using a Surber sampler $\left(0.09 \mathrm{~m}^{2} ; 250 \mu \mathrm{m}\right.$ mesh size $)$ and four in pools, using a Hess sampler $\left(0.025 \mathrm{~m}^{2} ; 250 \mu \mathrm{m}\right.$ mesh size). Different sampling devices were used because unlike the Surber, the Hess sampler can be used in the absence of current, which was the case in the pools. Moreover, sampling effort was higher in riffles than in pools due to the high amounts of sediment and fine debris in the pool samples. Samples were transported in a cooler to the laboratory, where the invertebrates were sorted live within $48 \mathrm{~h}$ and all coarse particulate organic matter (CPOM) removed. Ash-free dry mass (AFDM) was determined to the nearest $0.1 \mathrm{mg}$. Specimens of L. hirtum were counted and the distance between eyes (E.D.) was measured (precision $20 \mu \mathrm{m}$ ) using a dissecting microscope with an ocular micrometer.

Estimation of individual larval mass was done by a size-mass regression: a group of 46 animals were photographed on a dissection microscope (Wild Heerbrugg ${ }^{\circledR} 25 \times$, in which a video camera was inserted - Sony DXC-107AP ${ }^{\circledR}$ ), and their E.D. was measured from computer pictures, using Coreldraw $9^{\circledR}$. The case was removed from each specimen and dry mass $\left(60{ }^{\circ} \mathrm{C}, 48 \mathrm{~h}\right)$ and ash content $\left(550{ }^{\circ} \mathrm{C}, 5 \mathrm{~h}\right)$ determined. With these data, we built a regression model to calculate AFDW (mg) from E.D. (mm): AFDW $=0.0409 * \mathrm{e}^{3.451 * \mathrm{ED}}, n=46 ; R^{2}=0.7031$. Secondary production of $L$. hirtum was estimated using the size-frequency method, as explained in Benke (1984).

\section{Growth}

The purpose of this experiment was to investigate how temperature and leaf type affect growth rates of L. hirtum. Four standard temperatures were selected: 9, 12, 15 and $18{ }^{\circ} \mathrm{C}$, representing some typical summer and winter temperatures found in the field (González \& Graça, 2003). The photoperiod was set to $12: 12 \mathrm{~h}$ light/dark.

Specimens of L. hirtum were collected from the stream from October 2001 to September 2002 and placed in beakers with aerated stream water. They were fed with a mixture of chestnut, oak, poplar and alder leaves during a 1-week acclimation period. The individual mass of each specimen was 
calculated from its E.D., using the size-mass regression shown above.

As food, leaves from four tree species were selected: alder, Alnus glutinosa L.; oak, Quercus andegavensis; poplar, $P . \times$ canadensis Moench and chestnut, $C$. sativa Mill. Recently shed alder and poplar leaves were gathered from the soil surface in autumn, and senescent oak and chestnut leaves were collected directly from trees. They were airdried and stored in the dark. Before being offered as food to the animals, leaves were kept in $0.5 \mathrm{~mm}$ mesh bags and conditioned for 2 weeks in the stream.

Twenty larval specimens of L. hirtum (0.2$0.4 \mathrm{mg}$ AFDW) were reared at each temperature and diet. They were individually allocated into beakers with filtered stream water, which were aerated by plastic pipette tips connected to an air pump. Water and food were renewed weekly, and animals measured again after 4 weeks. Growth was given by the difference in mass (log AFDW), divided by time in days.

\section{Fragmentation}

The goal of this experiment was to determine how temperature and leaf type affect leaf fragmentation rates, assumed to be proportional to feeding rates. The term fragmentation is here applied, because L. hirtum use leaves as food but also as building material for the case, making food consumption difficult to measure directly. Specimens with an initial mass distribution of $0.8-1.5 \mathrm{mg}$ AFDW were reared in beakers at the same temperature and leaf types as described above. A known amount of leaves was provided in the form of leaf discs. Pairs of $9 \mathrm{~mm}$-diameter discs were obtained with a cork borer from contiguous areas of a same leaf, assuming that the two discs from the same pair had identical mass.

We reared specimens of $L$. hirtum individually in beakers containing two pairs of leaf discs. One disc from each pair (exposed) was accessible to L. hirtum, while the other one (control) was enclosured in a fine mesh $(0.5 \mathrm{~mm})$ envelope, next to the surface of the water.

After $72 \mathrm{~h}$, discs were removed, dried at $60{ }^{\circ} \mathrm{C}$ for at least $48 \mathrm{~h}$, weighed, burned at $550{ }^{\circ} \mathrm{C}$ for $5 \mathrm{~h}$ and reweighed, to determine AFDW. Fragmentation was computed as the difference between con- trol and exposed discs (mg), divided by time (days).

\section{Statistical analysis}

Differences between habitats (riffles and pools) and sampling dates for density and standing stocks of CPOM in benthos were tested using two-way ANOVA, followed by a Tukey test (Zar, 1996). The effect of temperature and leaf type on growth and fragmentation were also tested using two-way ANOVA followed by Tukey test when appropriate.

\section{Results}

\section{Growth and fragmentation experiments}

Mean growth rates of Lepidostoma hirtum ranged from 0.012 to $0.049 \mathrm{day}^{-1}$ for chestnut at $15^{\circ} \mathrm{C}$ and poplar at $15^{\circ} \mathrm{C}$, respectively. There were no significant differences (two-way ANOVA; $n=145$; $p>0.05$ ) between the leaf types given as food to the animals and nor among the temperatures to which they were subjected (Fig. 1).

Leaf fragmentation rates ranged from 0.41 to $1.81 \mathrm{mg}$ AFDW leaf animal ${ }^{-1} \mathrm{day}^{-1}$ for oak at $9{ }^{\circ} \mathrm{C}$ and alder at $12{ }^{\circ} \mathrm{C}$, respectively. Unlike growth, fragmentation rates were affected by both temperature and leaf type (two-way ANOVA; $p<0.05$ in both cases, Table 1, Fig. 2). They were significantly lower at $9{ }^{\circ} \mathrm{C}$ than at any other temperature and significantly different among all leaves, with higher fragmentation rates occurring with alder, followed by chestnut, poplar and oak (Table 1, Fig. 2).

\section{Population dynamics}

The stock of benthic organic matter ranged from $0.8 \mathrm{mg}$ AFDW (January, pools) to $81.0 \mathrm{mg}$ AFDW in September in pools (González \& Graça, 2003). Densities of L. hirtum were significantly correlated with the organic matter content in riffles (Spearman Rank Correlation, $p<0.05$; Fig. 3).

Density of L. hirtum at S. João stream ranged from 11 ind. $\mathrm{m}^{-2}$ (December, riffles) to 1389 ind. $\mathrm{m}^{-2}$ (September, riffles; Fig. 3). In a yearly basis, there were no significant differences between riffles and pools (ANOVA; $n=110$; 


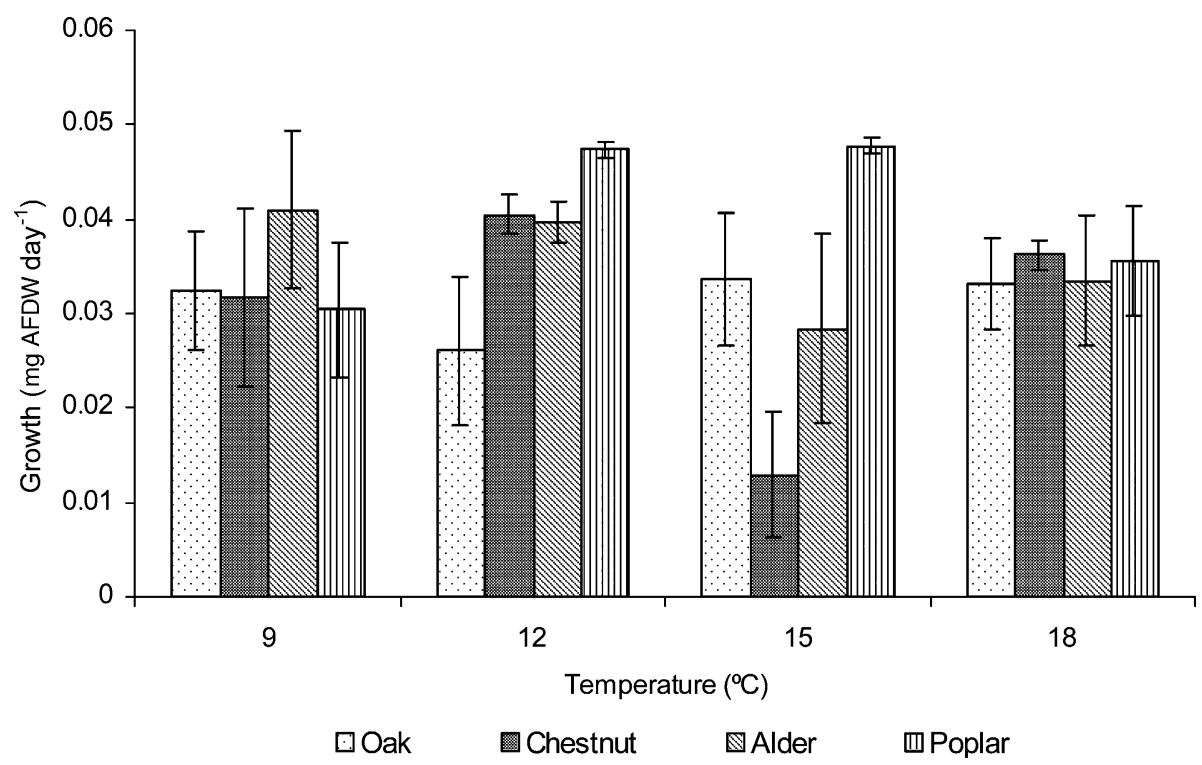

Figure 1. Growth rates of Lepidostoma hirtum in terms of daily increase in size for four leaf types and temperatures (mean and standard error).

$p>0.05$ ). In October the densities of L. hirtum were significantly higher than in December, February, March, April and May (Tukey test, $p<0.05$ ).

Lepidostoma hirtum larvae appear to have only one cohort in this year (Fig. 4) with recruitment from May to November. This large recruitment period results in a great asynchrony, due to the coexistence of larvae of different sizes, during practically the entire year, especially between July and October.

For production calculations, a Cohort Production Interval (Benke, 1979) of 12 months (the maximum value for univoltine populations) was used. Overall secondary production of L. hirtum in S. João stream was $60.92 \mathrm{mg} \mathrm{m}^{-2}$ year $^{-1}$, with a production of $53.95 \mathrm{mg} \mathrm{m}^{-2}$ year $^{-1}$ in pools and $63.12 \mathrm{mg}$ $\mathrm{m}^{-2}$ year $^{-1}$ in riffles. The overall annual Production/

Table 1. Two-Way ANOVA and Tukey test for fragmentation rates of $L$. hirtum with four leaf types at four temperatures

\begin{tabular}{llll}
\hline Source & $\begin{array}{c}\text { Values } \\
\text { of } F\end{array}$ & $\begin{array}{l}\text { Values } \\
\text { of }\end{array}$ & Tukey Test \\
\hline Temperature $\left({ }^{\circ} \mathrm{C}\right)$ & 13.997 & $<0.05 \quad(18=15=12)>9$ \\
Leaf type & 59.258 & $<0.05 \quad \mathrm{Ag}>\mathrm{Cs}>\mathrm{Pc}>\mathrm{Qa}$ \\
Temperature $\times$ Leaf type & 1.218 & 0.280 & \\
\hline
\end{tabular}

$\mathrm{Ag}=$ Alnus glutinosa $; \mathrm{Pc}=$ Populus $\times$ canadensis $; \mathrm{Cs}=$ Castanea sativa.
Biomass $(\mathrm{P} / \mathrm{B})$ ratio was 4.4 year $^{-1}$, with a ratio of $4.01 \mathrm{year}^{-1}$ in pools and 4.49 year $^{-1}$ in riffles.

\section{Discussion}

\section{Fragmentation}

The maximum leaf fragmentation rate by L. hirtum was $1.61 \mathrm{mg}$ leaf animal ${ }^{-1} \mathrm{day}^{-1}$, for individuals fed on alder leaves. Those values are comparable to the reported feeding rates of other shredders fed similar leaves and temperatures (Table 2). Oak was the least fragmented leaf type, which is comparable to some earlier studies. The low feeding/fragmentation rate is probably due to leaf physicalchemical characteristics, such as low nitrogen content (Irons et al., 1988) and high toughness (Oliveira, 2003). Fragmentation rates are an indicator of consumption rates, and the sequence obtained in this paper is consistent with other similar works, with this shredder using alder in preference to tougher leaves (Iversen, 1974; Irons et al., 1988; Friberg \& Jacobsen, 1994, 1999; Jacobsen \& Friberg, 1995; González \& Graça, 2003).

Therefore, processing rates of leaves (feeding plus material incorporated in the cases) by L. hirtum are similar to feeding rates reported for other shredders. 


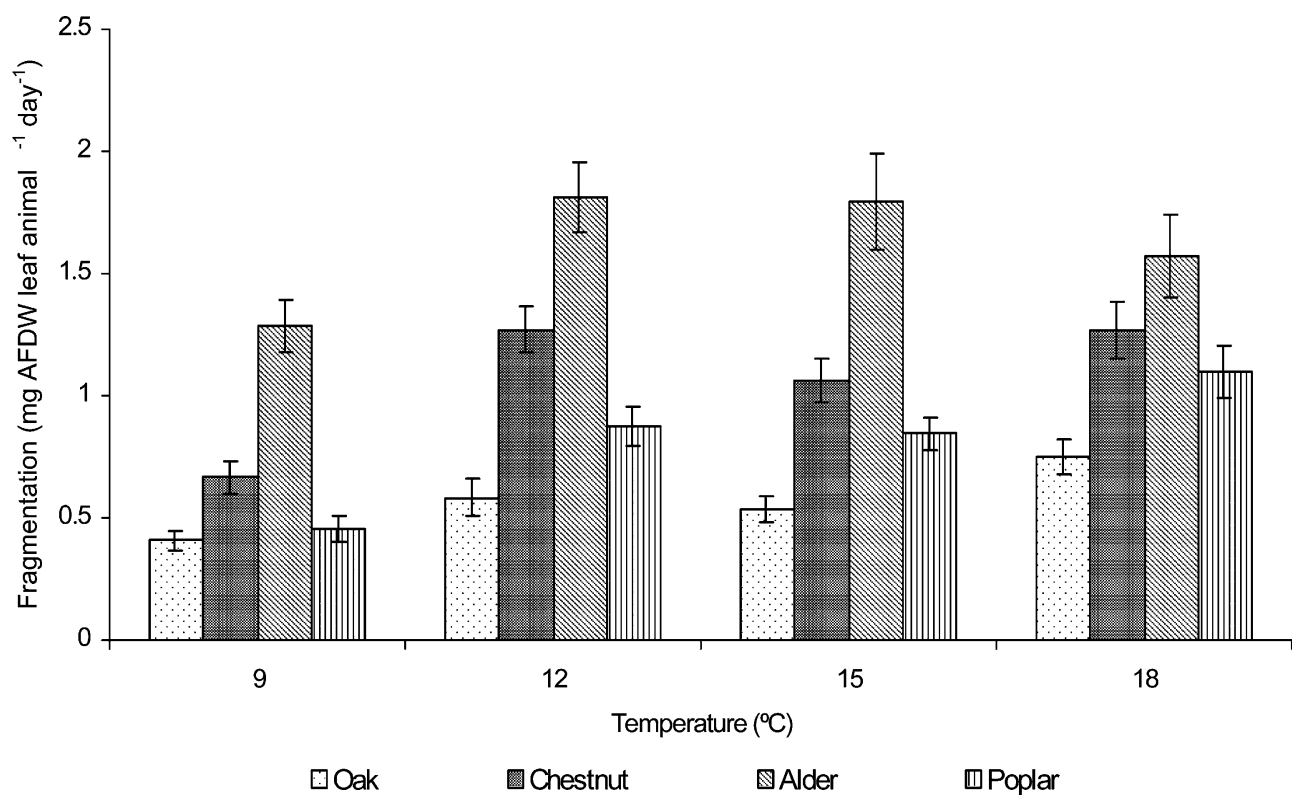

Figure 2. Fragmentation rates of leaves caused by feeding activities of Lepidostoma hirtum fed on four leaf types and 4 temperatures (Mean and standard error).

The sequence alder $>$ chestnut $>$ poplar $>$ oak is similar to findings of González \& Graça (2003) for the coexisting Sericostoma vittatum, but in that case poplar and chestnut were in reverse order.
The high value of alder leaves as a food resource is widely noted in the literature for other shredders (e.g. Iversen, 1974; Jacobsen \& Friberg, 1995; Haapala et al., 2001).

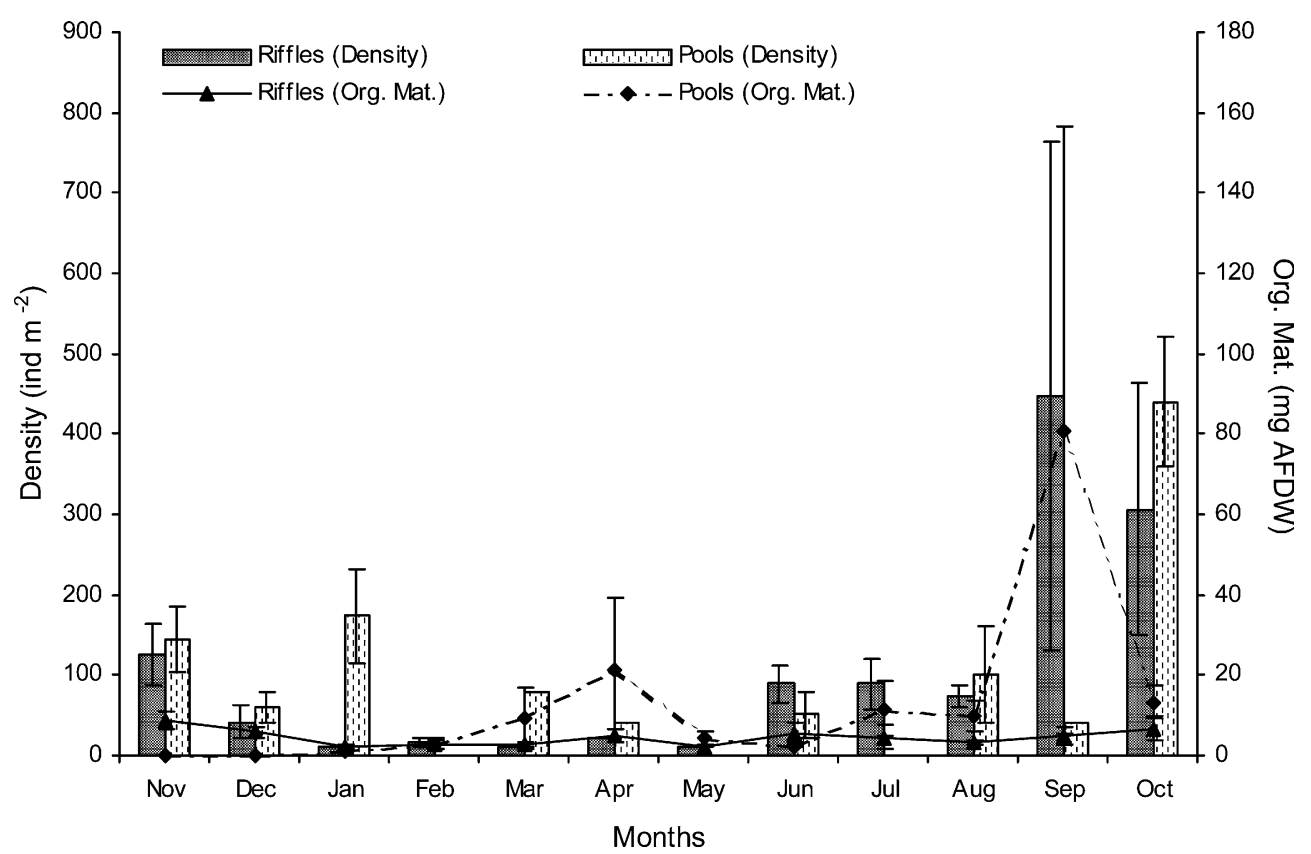

Figure 3. Temporal dynamics of L. hirtum densities, and total organic matter in riffles and pools of the S. João stream. Vertical bars represent standard error. 


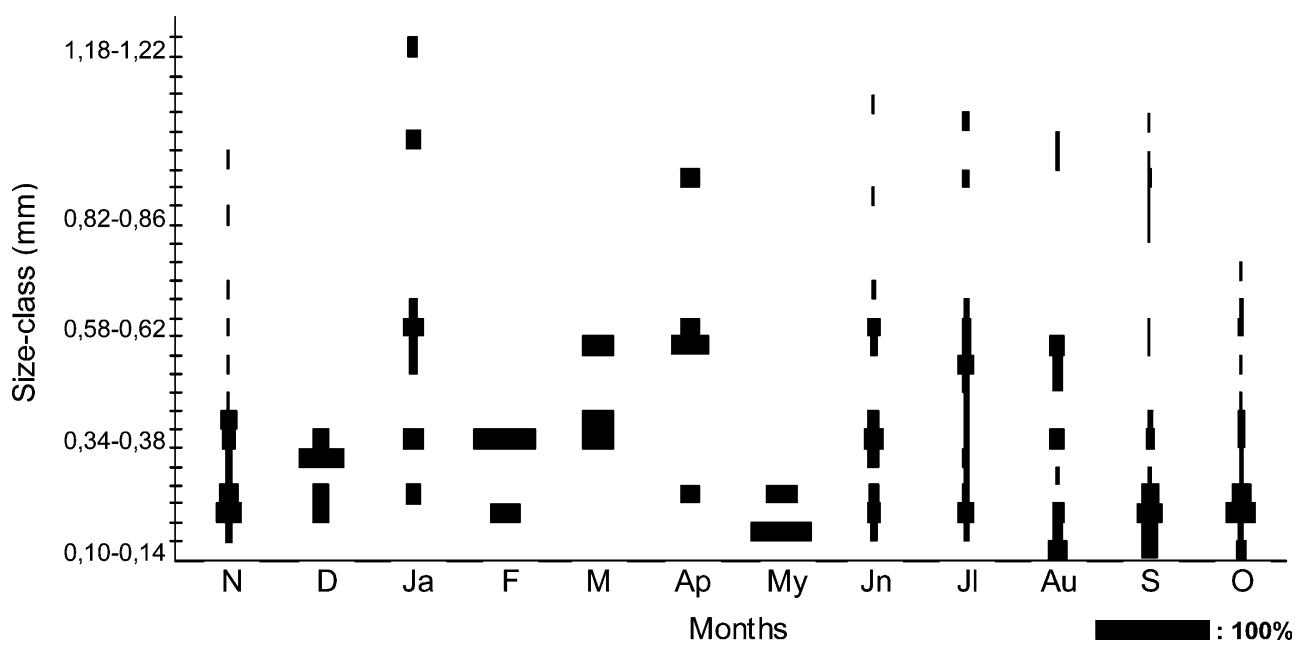

Figure 4. Size-frequency of Lepidostoma hirtum larvae from November 2000 to October 2001 in the S. João stream. The width of bars represents the percentage of larvae in each size-class, on a given sampling date.

Knowing that fragmentation rates were significantly lower at $9{ }^{\circ} \mathrm{C}$ than at any other tested temperature, and given that metabolism increases with temperature, fragmentation would be expected to increase in the same way. This relation was indeed described by Iversen (1979) for Sericostoma personatum (Spence) larvae (high ingestion rate at $13{ }^{\circ} \mathrm{C}$, increasing and decreasing above and below this value); by González \& Graça (2003) for $S$. vittatum larvae (maximum consumption rates between 15 and $18{ }^{\circ} \mathrm{C}$ ); and Grafius \& Anderson (1980) for Lepidostoma unicolor (Banks). The lack of differences in the range above $9{ }^{\circ} \mathrm{C}$ may be related with the high variability in fragmentation rates, which include feeding and use of leaves for case building.

\section{Growth}

We also did not find any measurable effect of temperature or leaf type on growth rates. In terms of temperature, we expected an increase in growth with temperature up to a plateau, as reported for other aquatic invertebrates such as Gammarus pulex (L.) (e.g. Sutcliffe et al., 1981). According to Iversen (1979), at temperatures higher than $13{ }^{\circ} \mathrm{C}$ the increase in consumption by $S$. personatum does not compensate for the increase in metabolic costs, causing a decrease in growth. In terms of food types, in general, consumers grow at high rates when high quality food is offered (e.g. Herbst,
1982; Friberg \& Jacobsen, 1994; González \& Graça, 2003). Still, some invertebrates increase their consumption rates when fed on low quality food, promoting, in this way, a constant growth rate (e.g. Anderson \& Cummins, 1979; Friberg \& Jacobsen, 1999). This food plasticity appears to be an advantage in environments where food resources vary seasonally or unpredictably, allowing consumers to move between a range of food resources of variable quality, without compromising significantly their growth performance (Graça et al., 2001b).

Our fragmentation rate experiment did not show this pattern of compensation feeding to allow constant growth. We conclude that a high individual variability in growth may have masked the factors leaf type and temperature in growth. Alternatively, this species may be very tolerant to temperature and food types, which is consistent with its wide distribution (Cummins, 1973; Moretti, 1983; Silveira \& Terra, 1994; and Vieira Lanero, 2000) and wide trophic niche (Basaguren et al., 2002).

\section{Population dynamics}

Larvae of Lepidostoma hirtum in the S. João stream had a univoltine life history, with one long recruitment period. The presence of final stage larvae during almost all the year, for this and for similar species, suggests a temporally extensive 


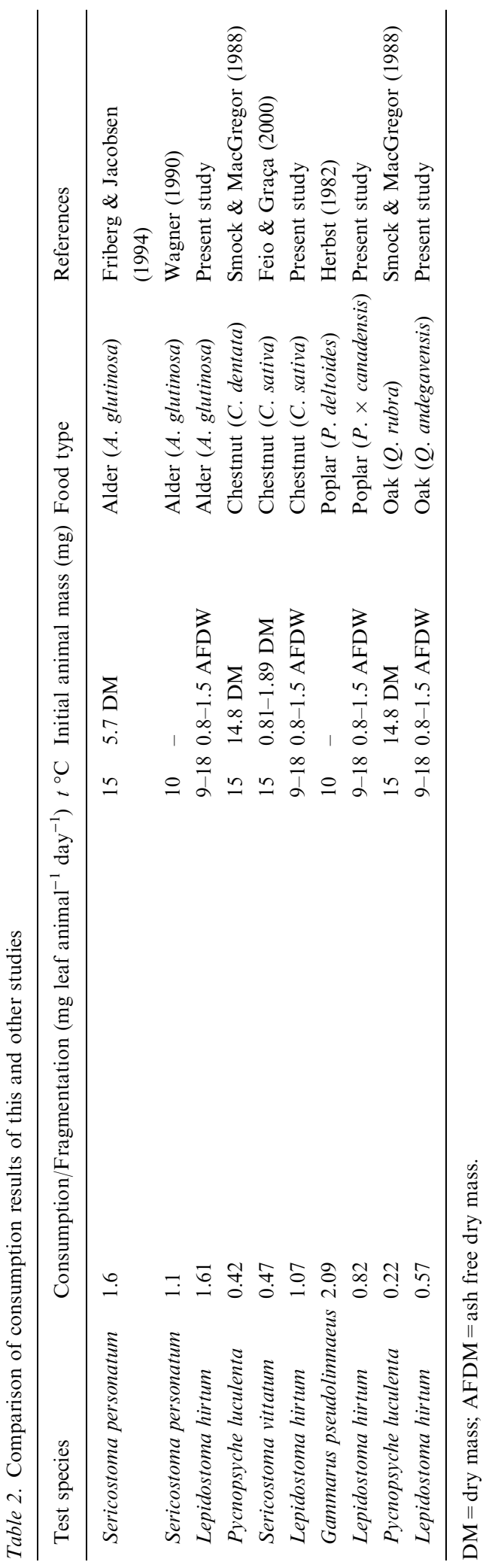


emergence period (Wallace et al., 1990; González, 2000). Basaguren et al. (2002) found the same pattern for this same species in a Basque Country (Spain) stream. The sympatric Sericostoma vittatum also has a univoltine life history (González \& Graça, 2003).

Anderson \& Cummins (1979) observed high growth rates of shredders during late autumn and winter, at the peak of leaf fall, and suggested that shredder life histories are synchronized to benefit from this pulse of high quality resources. However, despite high densities in late autumn and winter, the life history of L. hirtum does not seem to be tied to autumn output of leaves. Winterbourn et al. (1981) suggested that asynchronous (i.e. several size classes present at a given time) development could be viewed as a "bet-hedging" strategy in unpredictable environments. This seems to be the case of L. hirtum in S. João stream and is also observed for the other sympatric shredder S. vittatum (González \& Graça, 2003). Although we could expect a favourable environment for shredders in autumn because of the high litter input, this is also the season of high rains, with occasional floods washing away leaves and other plant detritus.

Densities of this species were similar in riffles and pools, but production was higher in riffles than in pools. This is consistent with other observations (Wohl et al., 1995; González \& Graça, 2003). We do not know the reason for the difference, but it could be related to additional food resources in riffles, or to higher accumulations of leaf detritus in riffles than in pools. González \& Graça (2003) found no correlation between $S$. vittatum abundance and CPOM stocks. Nonetheless, for the same period and the same river (present study), numbers of L. hirtum larvae and organic content were correlated in riffles (Spearman Rank Correlation, $p<0.05$ ). We do not know whether $L$. hirtum passively appears where organic matter accumulates, or if this species actively searches for patches with accumulated organic matter.

The secondary production $\left(60.92 \mathrm{mg} \mathrm{m}^{-2}\right.$ year $^{-1}$ ) found in the $\mathrm{S}$. João stream was very similar to that reported for $L$. hirtum $\left(69 \mathrm{mg} \mathrm{m}^{-2}\right.$ year $\left.^{-1}\right)$ in a Northern Spanish stream (González, 2000), but less than values reported for other Lepidostoma species in North American streams $\left(117 \mathrm{mg} \mathrm{m}^{-2}\right.$ year $^{-1}$; Lugthart \& Wallace, 1992; and $126 \mathrm{mg} \mathrm{m}^{-2}$ year $^{-1}$; Wohl et al., 1995), and lower than the production reported for the sympatric $S$. vittatum (441 $\mathrm{mg} \mathrm{m}^{-2}$ year $^{-1}$; González \& Graça, 2003).

Nevertheless, the $\mathrm{P} / \mathrm{B}$ ratios for both species were comparable: 4.4 year $^{-1}$ for L. hirtum and 4.95 year $^{-1}$ for the sympatric $S$. vittatum, similar to the ratio reported for Lepidostoma bryanti (Banks) on a North American stream 4.5 year $^{-1}$ (Krueger \& Waters, 1983) and within the range for other species: 6 year $^{-1}$ for Lepidostoma sp. (Lugthart \& Wallace, 1992).

\section{Leaf fragmentation in the stream}

The annual standing stock of CPOM for the study period was $6.3 \mathrm{~g} \mathrm{~m}^{-2}$, and the major organic matter input in the stream was composed of leaves of Acacia dealbata, Castanea sativa and Salix spp (González \& Graça, 2003). This value is much lower than that reported by Abelho \& Graça (1998) for other streams located in central Portugal $\left(157 \mathrm{~g} \mathrm{~m}^{-2}\right)$. The difference may be related to stream order. While Abelho and Graça (1998) worked in a 1st order stream, our study was carried out in a 4th-5th order reach. It is known that retention (and therefore standing stock of organic matter) decreases with increase in stream order (e.g. Abelho, 2001). For the period between November 2000 and October 2001, annual mean density of Lepidostoma hirtum larvae for the study site was 138 individuals $\mathrm{m}^{-2}$, with a maximum of 366 individuals $\mathrm{m}^{-2}$ in September 2001. Given that chestnuts are very abundant in the study area, we can assume that these leaves make the highest contribution to the stream. Knowing that these leaves were fragmented at an average rate of $1.07 \mathrm{mg}$ leaf $\mathrm{day}^{-1}$, we can take this value as a mean fragmentation rate for larvae of L. hirtum in this stream. We can calculate that, in the field, these animals can fragment around $138 * 1.07=147.7 \mathrm{mg}$ leaf $\mathrm{m}^{-2} \mathrm{day}^{-1}$, corresponding to $54 \mathrm{~g} \mathrm{~m}^{-2}$ per year. This value is again rather close to the one calculated by Iversen (1980) for larvae of $S$. personatum on a forest stream where the major arboreal species was beech $\left(50 \mathrm{~g} \mathrm{~m}^{-2}\right.$ year $\left.^{-1}\right)$, but higher than that reported for the sympatric $S$. vittatum (14-21 $\mathrm{g} \mathrm{m}^{-2}$ year $^{-1}$, González \& Graça, 2003). 
These fragmentation values represent around 8.6 times the annual mean standing stock of CPOM in the S. João stream. Probably this value is unrealistically high, since L. hirtum also feeds on other resources (Basaguren et al., 2002). Nevertheless, our results demonstrate that shredder invertebrates in streams have the capability to process large amounts of leaf litter. The fate of detritus in streams is very dynamic; it is quickly used by fungi and eaten by invertebrates at a very high rate. A continuous supply of leaf litter and feeding on alternative sources can explain the high productivity of invertebrates in low-order streams draining forested areas.

\section{Acknowledgements}

This research was supported by the Portuguese Science Foundation project POCT/BSE/32389/ 2000 and by the IMAR.

\section{References}

Abelho, M. \& M. A. S. Graça, 1998. Litter in a first-order stream of a temperate deciduous forest (Margaraça Forest, central Portugal). Hydrobiologia 324: 1-10.

Abelho, M., 2000. Once upon a time a leaf: from litterfall to breakdown in streams. Ph.D. Thesis, University of Coimbra, Portugal.

Abelho, M., 2001. From litterfall to breakdown in streams: a review. The Scientific World 1: 656-680.

Anderson, N. H. \& K. W. Cummins, 1979. Influences of diet on the life histories of aquatic insects. Journal of the Fisheries Research Board of Canada 36: 335-342.

Basaguren, A., P. Riaño \& J. Pozo, 2002. Life history and dietary changes of several caddisfly (Trichoptera) species in a northern Spain stream. Archiv für Hydrobiologie 155: 2341.

Benke, A. C., 1979. A modification of the Hynes method for estimating secondary production with particular significance for multivoltine populations. Limnology and Oceanography 24: 168-171.

Benke, A. C., 1984. Secondary production of aquatic insects. In Resh, V. H. \& D. M. Rosenberg (eds), The Ecology of Aquatic Insects. Praeger, New York, NY: 289-322.

Canhoto, C. \& M. A. S. Graça, 1996. Decomposition of Eucalyptus globulus leaves and three native leaf spp (Alnus glutinosa, Castanea sativa and Quercus faginea) in a Portuguese low order stream. Hydrobiologia 333: 79-85.

Cummins, K. W., 1973. Trophic relations of aquatic insects. Annual Review of Entomology 18: 183-206.
Dobson, M. \& A. G. Hildrew, 1992. A test of resource limitation among shredding detritivores in low order streams in southern England. Journal of Animal Ecology 61: 69-78.

Feio, M. J. \& M. A. S. Graça, 2000. Food consumption by the larvae of Sericostoma vittatum (Trichoptera), an endemic species from the Iberian Peninsula. Hydrobiologia 439: 7-11.

Fisher, S. G. \& G. E. Likens, 1973. Energy flow in Bear Brook, New Hampshire: an integrative approach to stream ecosystem metabolism. Ecological Monographs 43: 421-439.

Friberg, N. \& D. Jacobsen, 1994. Feeding plasticity of two detritivore-shredders. Freshwater Biology 32: 133-142.

Friberg, N. \& D. Jacobsen, 1999. Variation in growth of the detritivore-shredder Sericostoma personatum (Trichoptera). Freshwater Biology 42: 625-635.

Gee, J. H. R., 1988. Population dynamics and morphometrics of Gammarus pulex L.: evidence of seasonal food limitation in a freshwater detritivore. Freshwater Biology 19: 333-343.

González, J. M., 2000. Producción secundaria de macroinvertebrados fluviales de la cuenca del Agüera. Ph.D. thesis, Bilbao, Spain.

González, J. M. \& M. A. S. Graça, 2003. Conversion of leaf litter to secondary production by a shredding caddisfly. Freshwater Biology 48: 1578-1592.

Graça, M. A. S., 1993. Patterns and processes in detritus-based stream systems. Limnologica 23: 107-114.

Graça, M. A. S., R. C. F. Ferreira \& C. N. Coimbra, 2001a. Litter processing along a stream gradient: the role of invertebrates and decomposers. Journal of the North American Benthological Society 20: 408-420.

Graça, M. A. S., C. Cressa, M. O. Gessner, M. J. Feio, K. A. Callies \& C. Barrios, 2001b. Food quality, feeding preferences, survival and growth of shredders from temperate and tropical streams. Freshwater Biology 46: 947-957.

Grafius, E. \& N. H. Anderson, 1980. Population dynamics and role of two species of Lepidostoma (Trichoptera: Lepidostomatidae) in an Oregon woodland stream. Ecology 60: 433441.

Haapala, A., T. Muotka \& A. Markkola, 2001. Breakdown and macroinvertebrate and fungal colonization of alder, birch and willow leaves in a boreal forest stream. Journal of the North American Benthological Society 20: 395-407.

Herbst, G. N., 1982. Effects of leaf type on the consumption rates of aquatic detritívoros. Hydrobiologia 89: 77-87.

Irons, J. G. III, M. W. Oswood \& J. P. Bryant, 1988. Consumption of leaf detritus by a stream shredder: influence of 3 species and nutrient status. Hydrobiologia 160: 53-61.

Iversen, T. M., 1974. Ingestion and growth in Sericostoma personatum (Trichoptera) in relation to the nitrogen content of ingested leaves. Oikos 25: 278-282.

Iversen, T. M., 1979. Laboratory energetics of larvae of Sericostoma personatum (Trichoptera). Holarctic Ecology 2: 1-5.

Iversen, T. M., 1980. Densities and energetics of two streamliving populations of Sericostoma personatum (Trichoptera). Holarctic Ecology 3: 65-73.

Jacobsen, D. \& N. Friberg, 1995. Food preference of the trichopteran larva Anabolia nervosa from two streams with different food availability. Hydrobiologia 308: 139-144. 
Krueger, C. C. \& T. F. Waters, 1983. Annual production of macroinvertebrates in three streams of different water quality. Ecology 64: 840-850.

Lugthart, J. G. \& J.B. Wallace, 1992. Effects of disturbance on benthic functional structure and production in mountain streams. Journal of the North American Benthological Society 11: 138-164.

Moretti, G., 1983. Tricotteri (Trichoptera) - Guide per il riconoscimento delle specie animali delle acque interne italiane. Consiglio Nazionale delle Ricerche, Verona $155 \mathrm{pp}$.

Nolen, J. A. \& R. G. Pearson, 1993. Factors affecting litter processing by Anisocentropus kirranus (Trichoptera: Calamoceratidae) from an Australian tropical rainforest stream. Freshwater Biology 29: 469-479.

Oliveira, R., 2003. Polifenóis, dureza e azoto na alimentação de detritívoros. Master thesis. University of Coimbra, Portugal.

Silveira, L. \& W. Terra, 1994. Atlas provisório dos tricópteros (Insecta, Trichoptera) de Portugal Continental. Instituto Florestal, Estudos e formação, p. 306

Smock, L. A. \& C. A. MacGregor, 1988. Impact of the American chestnut blight on aquatic macroinvertebrates. Journal of the North American Benthological Society 7: 212-221.

Suberkropp, K. \& E. Chauvet, 1995. Regulation of leaf breakdown by fungi in streams: influences of water chemistry. Ecology 76: 1433-1445.
Sutcliffe, D. W., T. R. Carrick \& L. G. Willoughby, 1981. Effects of diet, body size, age and temperature on growth rates in the amphipod Gammarus pulex. Freshwater Biology 11: 183-214.

Vieira Lanero, R., 2000. Las larvas de los tricópteros de Galicia (Insecta: Trichoptera), Ph.D. thesis, Universidade de Santiago de Compostela, Spain.

Wagner, R., 1990. A laboratory study on the life cycle of Sericostoma personatum (Kirby \& Spence) and light darkdependent food consumption. Hydrobiologia 208: 201-212.

Wallace, I. D., B. Wallace \& G. N. Philipson, 1990. A key to the case-bearing caddis larvae of Britain and Ireland. Freshwater Biological Association 51 .

Winterbourn, M. J., J. S. Rounick \& B. Cowie, 1981. Are New Zealand stream ecosystems really different?. New Zealand Journal of Marine and Freshwater Research 15: 321-328.

Wohl, D. L., J. B. Wallace \& J. L. Meyer, 1995. Benthic macroinvertebrate community structure, function and production with respect to habitat type, reach and drainage basin in the southern Appalachians (U.S.A.). Freshwater Biology 34: 447-464.

Zar, J. H., 1996. Biostatistical Analysis (3rd ed.). Prentice Hall, Upper Saddle River, NJ. 